University of South Carolina

Scholar Commons

\title{
Role of a Phase: Change Moho in Stabilization and Preservation of the Southern Uralide Orogen, Russia
}

\author{
Camelia C. Diaconescu \\ University of South Carolina - Columbia, camelia@geol.sc.edu \\ James H. Knapp \\ University of South Carolina - Columbia, knapp@geol.sc.edu
}

Follow this and additional works at: https://scholarcommons.sc.edu/geol_facpub

Part of the Earth Sciences Commons

\section{Publication Info}

Published in AGU Monograph Series, ed. D. Brown, C. Juhlin, \& V. Puchkov, Volume 132, 2002, pages

67-82.

Diaconescu, C. C. \& Knapp, J. H. (2002). Role of a phase: Change Moho in stabilization and preservation of the southern Uralide Orogen, Russia. AGU Monograph Series, 132, 67-82.

(CAGU Monograph Series 2002, American Geophysical Union

This Article is brought to you by the Earth, Ocean and Environment, School of the at Scholar Commons. It has been accepted for inclusion in Faculty Publications by an authorized administrator of Scholar Commons. For more information, please contact digres@mailbox.sc.edu. 


\title{
Role of a Phase: Change Moho in Stabilization and Preservation of the Southern Uralide Orogen, Russia
}

\author{
Camelia C. Diaconescu ${ }^{1,2,3}$ and James H. Knapp ${ }^{1,2}$ \\ ${ }^{I}$ University of South Carolina, South Carolina, USA \\ ${ }^{2}$ Cornell University, Ithaca, New York, USA \\ ${ }^{3}$ National Institute for Earth Physics, Bucharest-Magurele, Romania
}

\begin{abstract}
Geophysical (URSEIS experiment) and geological data from the Southern Uralides of central Russia provide the basis for a geodynamic model involving eclogitization of the Uralian crustal root in Late Triassic to Early Jurassic time as a mechanism for stabilization and preservation of this Paleozoic orogen. The crustal structure of the orogen implies eastward subduction of the East European continental crust, and balanced restoration implies a significant volume of crust (comprised of $\sim 70 \%$ European crust, and $\sim 30 \%$ accreted terranes) was carried to sub-Moho depths of up to $70 \mathrm{~km}$. The lack of a clearly defined near-vertical incidence reflection Moho corroborated by coincident wide-angle reflection data suggest that the Moho is a sub-horizontal gradational boundary at $\sim 50-53 \mathrm{~km}$ depth beneath the axis of the Southern Uralides. Previous modeling of a subdued ( -50 mgal) regional Bouguer gravity minimum across the orogen suggests a subsurface load that is interpreted here as substantiation for a metamorphic phasechange of the lower crust to mantle-like eclogite facies rocks. Timing of eclogitization appears to be constrained by (1) superposition of a nearly flat Moho across the Paleozoic Uralian orogenic fabric, and (2) zircon and apatite fission-track minimum ages of 180-200 Ma, marking an upper age limit to cooling of rocks exposed at the surface, and, implicitly, to significant uplift and erosion in the Southern Uralides. The proposed eclogitization of the Southern Uralian root zone may have led to an isostatically balanced system with subdued topography, and thereby presumably served to stabilize and preserve the orogenic structure.
\end{abstract}

Mountain Building in the Uralides: Pangea to the Present Geophysical Monograph 132

Copyright 2002 by the American Geophysical Union

10.1029/132GM05

\section{INTRODUCTION}

Seismological investigations in orogenic settings in recent years have led to a revised integration of the two classic views of isostatic compensation of mountain belts (Airy vs. Pratt equilibrium). New studies [Jones et al., 1994; Wernicke et al., 1996] indicate that orogenic loads can in large part be supported by density heterogeneities 


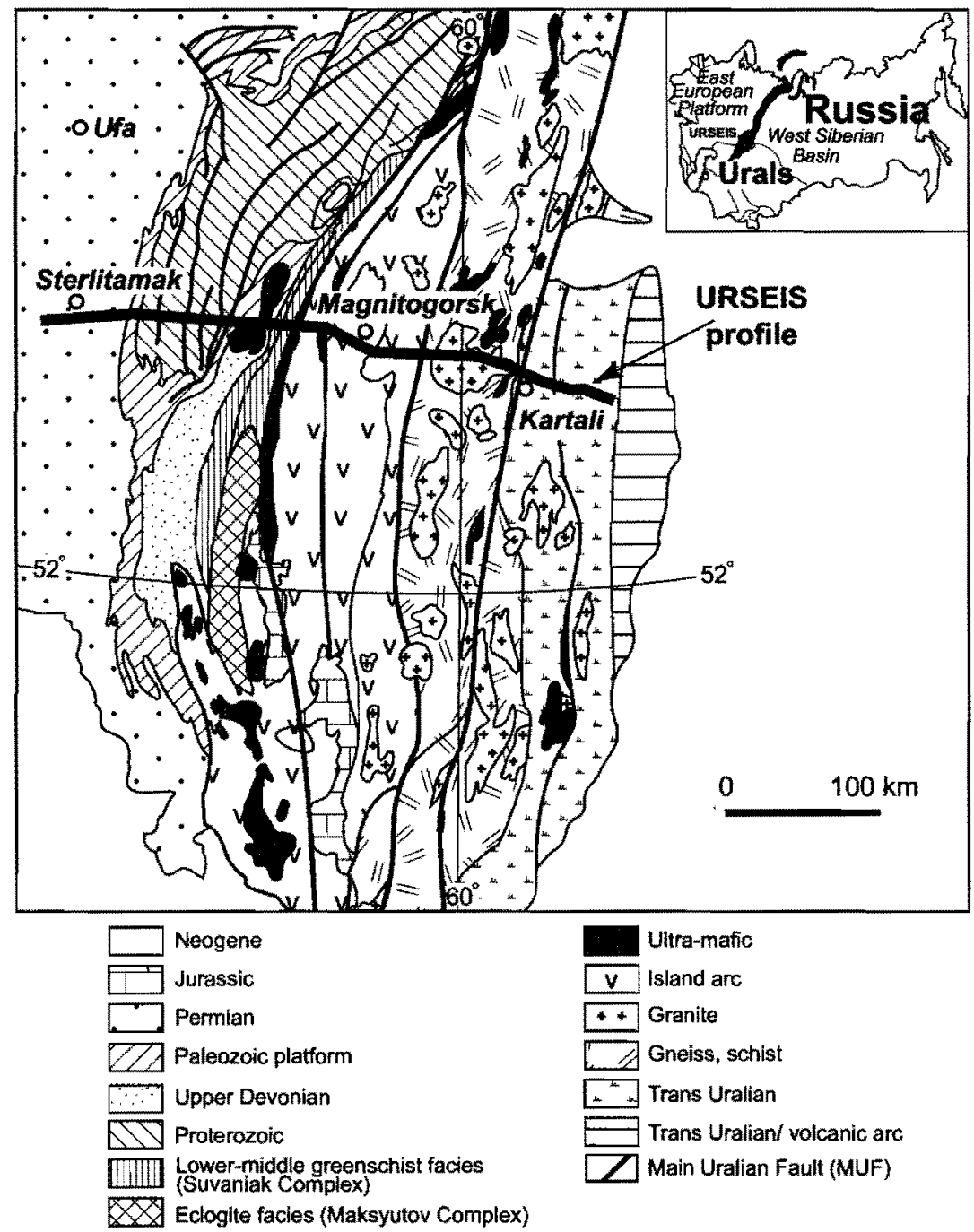

Figure 1. Location map of the URSEIS deep seismic profile showing the principal tectonic elements of the Southern Uralides (modified after Berzin et al., 1996).

in the lower crust or upper mantle rather than exclusively by thickening of the crust. While results from young mountain belts, such as the Sierra Nevada, suggest that high elevations may be supported by low density bodies in the upper mantle [e.g., Ducea and Saleeby, 1996; Jones and Phinney, 1998], analyses of older mountain belts document various mechanisms for isostatic compensation. Seismic profiles from the Archean age Baltic [BABEL Working Group, 1990] and Canadian [Henstock et al., 1998] shields suggested that they have been stable for over $1.5 \mathrm{Ga}$ and still preserve their crustal roots as revealed by depressed Moho boundaries with significant relief. In contrast, Paleozoic orogens such as the Appalachians, Caledonides, and Variscides underwent post-orogenic collapse and extension as indicated by relatively flat and shallow Mohos and the wide Atlantic Ocean in between [Cook et al., 1979; Meissner et al., 1987; Nelson et al,, 1987; Andersen et al., 1991; Boundy et al., 1992; Austrheim et al., 1997].

A notable exception to the extended Paleozoic orogens is the Southern Uralide orogen of Central Russia (Figure 1), which still preserves its collisional architecture [Hamilton, 1970; Druzhinin et al., 1988; Berzin et al., 1996; Carbonell et al., 1996; Echtler et al., 1996; Knapp et al., 1996]. A regional Bouguer gravity minimum ( $-50 \mathrm{mgal})$ and the lack of significant topographic relief across the axis of the orogen make the Southern Uralides yet another example of an 
orogenic belt where the thickening of the crust does not exclusively support the mountain load [Druzhinin et al., 1988, 1990; Kruse and McNutt, 1988]. However, while the Southern Uralides seem to have preserved their orogenic structure for over $250 \mathrm{Ma}$ without undergoing orogenic collapse and post-orogenic extension, there is evidence that the Middle Uralides were affected by early Mesozoic extension as indicated by Knapp et al. [1998].

Earlier geophysical investigations of the Southern Uralides indicated that a pronounced crustal root (10-15 km thick) underlies the orogen [Druzhinin et al., 1988, 1990; Thouvenot et al., 1995; Berzin et al., 1996; Carbonell et al., 1996; Echtler et al., 1996; Juhlin et al., 1996; Knapp et al., 1996]. The presence of a Uralian crustal root has long been a subject of controversy since the crust appears to be much thicker than required for the compensation of the subdued topography [Kruise and McNutt, 1988; Döring and Götze, 1999]. The URSEIS (Urals Seismic Experiment and Integrated Studies) deep seismic profile across the Southern Uralides displays a highly reflective subhorizontal Moho reflection at $\sim 42-45 \mathrm{~km}$ depth beneath the Uralian foreland and hinterland (Figure 2a). While the subhorizontal Moho on both sides of the orogen deepens gently toward the central part of the orogen, it loses the pronounced reflective character and cannot be clearly identified on the seismic reflection profile. Previous interpretations of this relationship involved projection of the Moho boundary to depths of $\sim 60 \mathrm{~km}$ [Berzin et al., 1996; Carbonell et al., 1996, 1998]. More recent analysis of the velocity structure of the crustal root suggests it is characterized by high P-wave velocity $(7.7-8.0 \mathrm{~km} / \mathrm{s})$ [Druzhinin et al., 1988; Thouvenot et al., 1995; Carbonell et al., 1998, 2000], and it was interpreted as either remnant of the Paleozoic collision [Kruise and McNutt, 1988] or interlayered sequences of eclogites and peridotites [Carbonell et al., 2000].

An increasing number of multidisciplinary studies of collisional zones and an abundance of geophysical data in the past years suggest that the composition and structure of the continental lower crust may play a critical role in the geodynamic development of mountain belts [Laubscher, 1990; Andersen et al., 1991; Dewey et al., 1993; Platt and England, 1994; Baird et al., 1996; Wernicke et al., 1996; Austrheim et al., 1997; Le Pichon et al., 1997]. Of particular interest lately has been the metamorphic phase-change of the orogenic lower crust to eclogite facies rocks, as this process is being considered responsible for gravitational destabilization of orogenic belts. Partial or full metamorphic phase change of the thickened lower crust from granulite to eclogite facies assemblages was proposed in a number of orogenic belts, such as the Norwegian Caledonides, Variscides, Alps, Himalayas, and Trans-Hudson orogen [Laubscher, 1990; Austrheim, 1991; Andersen et al., 1991; Dewey et al., 1993; Baird et al., 1995]. Eclogitization of orogenic roots was suggested as a mechanism of triggering delamination of the lower crust and uppermost mantle [Laubscher, 1990; Bousquet et al., 1997], delamination followed by collapse and post-orogenic extension [Austrheim, 1990; Austrheim et al., 1997], or subsidence of the overlying upper crust and subsequent formation of sedimentary basins [Baird et al., 1995, 1996]. Conversely, retrogression of eclogite to granulite facies rocks was proposed as a mechanism for large-scale uplift without surface shortening [Le Pichon et al., 1997]. Since high pressure rocks are only exposed in a few orogenic sections worldwide, deep seismic profiling and mass balance techniques have been used lately to remotely study deep orogenic roots [e.g., Laubscher, 1990].

Here we present a model for post-orogenic eclogitization of the Southern Uralide crustal root that rests on a series of geophysical (seismic, gravity, thermal) and geological (crustal restoration, fission track, surface geology) data. Furthermore, we compare the Southern Uralides with other orogens of different ages that were proposed to have experienced eclogitization of the crustal roots, and discuss possible scenarios in support of long-lived stability of orogenic systems and mechanisms for isostatic compensation unrelated to crustal thickness.

\section{GEOLOGIC FRAMEWORK}

The Urals of Central Russia form the modern geographic boundary between Europe and Asia, and resulted from the Late Paleozoic collision between the East European and Siberian cratons through a collage of island arcs and microcontinental terranes in between the two cratons [Sengör et al., 1993]. The Urals together with the Appalachians, the Caledonides, and the Variscides comprise the major zones of continental convergence that contributed to the edifice of the Late Paleozoic Pangea supercontinent [Hamilton, 1970; Sengör et al., 1993].

Formation of the Uralides began with rifting and development of a passive continental margin on the East European platform in Late Cambrian to early Ordovician time [Hamilton, 1970; Zonenshain et al., 1984]. The subsequent tectonic evolution of the Uralides involved amalgamation of various lithospheric elements during the Permian or early Triassic time, with formation of island arcs, back-arc basins, and oceanic crust by successive convergence of the East European platform, Siberian 


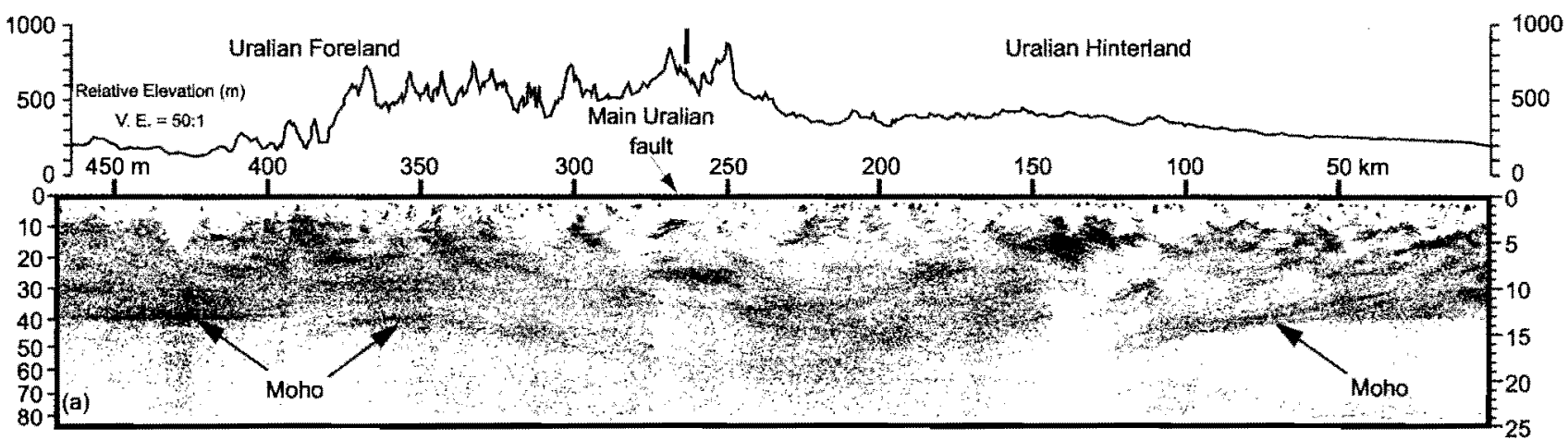

$(\mathrm{km})$

Zircon age (Ma)

Apatite age (Ma)
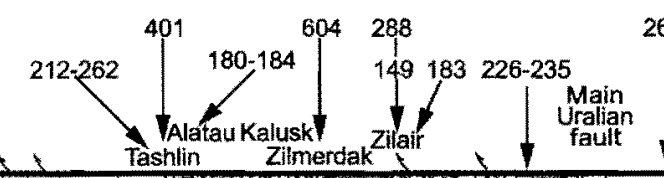

263

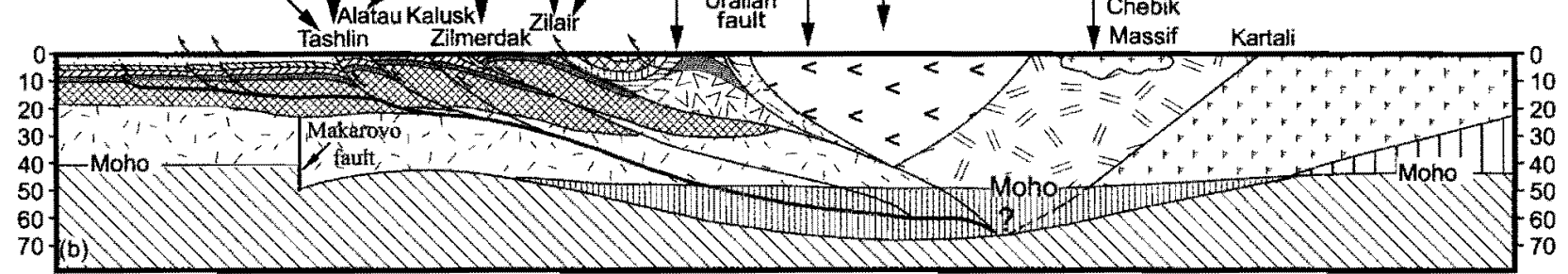

(km)

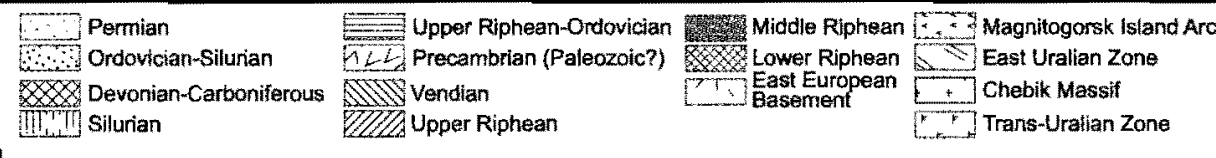

DIIIIII] Eciogitzed Lower Crust $(\mathrm{km})$

IIJ siberian Craton

S. Mantie Lithosphere
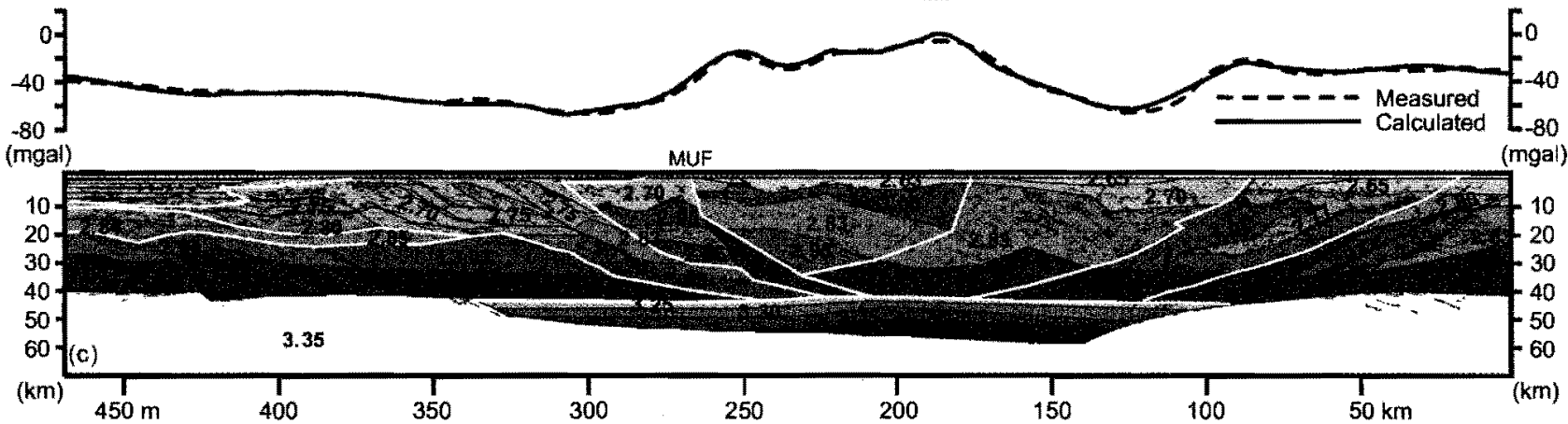

Figure 2. (a) Migrated time section of the URSEIS profile (modified after Knapp et al., 1996). (b) Crustal-scale cross-section of the URSEIS profile suggesting that the majority of the Uralian crustal root at $-53-70 \mathrm{~km}$ depth (horizontal pattern) is of East European affinity. Moho was picked as PmP arrivals on stacked versions of the wide-angle profile (Carbonell et al., 1998). Numbers on the top of cross-section represent cooling ages from zircon and apatite fission-track data after Seward et al. (1997); (c) Gravity model along the URSEIS profile showing crustal densities and their calculated versus measured Bouguer gravity effect (adapted from Döring and Götze, 1999).

craton, and Kazakhstan [Hamilton, 1970; Zonenshain et al., 1984; Zonenshain et al., 1990; Puchkov, 1996].

Earlier studies suggested that the Uralides exhibit several superficial geometric similarities with other orogens of Paleozoic age such as the Appalachians, Ouachitas, Variscides or Caledonides including a highly imbricated transition zone from the foreland basin to the hinterland [e.g., Rodgers, 1990]. However, fundamental differences were recognized including a thick-skinned foreland fold and thrust belt and reduced shortening for the Uralides [Brown et al., 1996] as well as the presence of a pronounced Uralide crustal root [Druzhinin et al., 1988; Carbonell et al., 1996; Juhlin et al., 1996; Knapp et al., 1996; Steer et al., 1998]. 
The foreland fold and thrust belt of the Southern Uralides forms a west-vergent thrust system west of the Main Uralian fault (the inferred Paleozoic suture between the East European craton to the west and accreted terranes to the east) involving both Paleozoic and Precambrian strata in the deformation [Zonenshain et al., 1990; Brown et al., 1996, 1997]. The Riphean and Vendian sections attain thicknesses in excess of $19 \mathrm{~km}$ and were extensively deformed during the Late Paleozoic time with predominantly west vergent thrusting [Skripiy and Yunusov, 1989; Brown et al., 1997]. A wide zone of deformation, in which Permian strata have been folded into ramp anticlines cored by blind thrusts (Figure 1) [Skripiy and Yunusov, 1989; Brown et al., 1997; Diaconescu et al., 1998], marks the transition from the foreland basin to the foreland fold and thrust belt.

An early phase of eclogitization in the Southern Uralides is clearly recorded in the Maksyutov Complex, a $15 \times 200 \mathrm{~km}$ body in the footwall of the Main Uralian fault (Figure 1). Lennykh et al. [1995], Hetzel et al. [1998], Dobretsov et al. [1996], and Beane [1997] suggested that this complex consists of three main rock types including high-pressure eclogite facies rocks, metasandstones (blueschist-facies), and a metamorphosed maficultramafic melange (greenschist facies). The protolith and the metamorphic age of the rocks forming the Maksyutov Complex remain a subject of controversy [e.g., Zakharov and Puchkov, 1994; Hetzel, 1999; Leech and Stockli, 2000]. However, metamorphosed mafic and quartz-rich rocks exposed in the Maksyutov Complex preserve evidence for a Paleozoic high-pressure metamorphic event during the assembly of the Southern Uralides [Matte et al., 1993; Beane et al., 1995, 1997; Hetzel et al., 1998; Beane and Connelly, 2000; Leech and Stockli, 2000].

The Uralian hinterland, east of the Main Uralian fault (Figure 1), consists of several island are assemblages, microcontinents, and ophiolite suites that were obducted onto the East European craton throughout the late Paleozoic until Early Carboniferous time. The island arcs were interpreted to be Devonian and Early Carboniferous in age and were amalgamated east of the inferred east-dipping subduction zone [Zonenshain et al., 1990; Berzin et al., 1996].

\section{CRUSTAL-SCALE RESTORATION}

Balanced-cross sections have proven to be a powerful technique for understanding the deformation style in foreland fold and thrust belts [e.g., Dahlstrom, 1970; Allmendinger et al., 1990]. While this technique was initiated through structural interpretations of orogenic systems from surface geologic information [Dahlstrom, 1970], it was subsequently developed to constrain crustal-scale interpretations from deep seismic reflection profiles including structural and lithologic boundaries, main detachments and/or the base of the crust [Allmendinger et al., 1990].

A recently acquired $\sim 500-\mathrm{km}$ dynamite and vibroseis near-vertical and wide-angle incidence deep seismic reflection profile (URSEIS) across the Southern Uralides provides an excellent means for investigating the crustal architecture and composition of this orogen through use of crustal-scale balanced sections [Berzin et al., 1996; Carbonell et al., 1996; Echtler et al., 1996; Knapp et al., 1996] (Figure 1). The Southern Uralides, as shown by the URSEIS profile, constitute a bivergent orogen with highly reflective structures within the crust, both in the foreland basin and hinterland (Figure 1) [e.g., Berzin et al., 1996]. A clear image of the Moho boundary was obtained in both the Uralian foreland to (the west) and hinterland (to the east) at approximately $42-45 \mathrm{~km}$ (Figure 2a), as indicated by an abrupt downward change in reflectivity. This well-defined Moho reflection dies out toward the central part of the orogen that is dominated by a zone of diffuse reflectivity (175-300 km distance in Figure 2a). However, the Moho was previously projected to a depth of $60 \mathrm{~km}$ and interpreted to represent the base of the crustal root from initial processing of the wideangle data and the downward diminution of the zone of diffuse reflectivity beneath the axis of the orogen [Carbonell et al., 1996; Knapp et al., 1996; Steer et al., 1998].

Several interpretations of the URSEIS near-vertical incidence vibroseis and dynamite seismic sections have already been published by Berzin et al. [1996], Echtler et al. [1996], Diaconescu et al. [1998], and Döring and Götze [1999]. Here we attempt to reinterpret the combined URSEIS vibroseis (upper $7 \mathrm{~s} / 20 \mathrm{~km}$ ) and dynamite (down to $25 \mathrm{~s} / \sim 80 \mathrm{~km}$ ) sections based on (1) reflection character throughout the crust, (2) surface geology, and (3) crustal-scale restoration of the Southern Uralide fold and thrust belt west of the Zilair fault. While there have been recent efforts to restore the Southern Uralian foreland fold and thrust belt based on surface geologic information [Brown et al., 1996, 1997, 1998; Perez-Estaun et a1., 1997], here we present an attempt to restore on a crustal-scale a fairly detailed cross section of this part of the URSEIS profile west of the Zilair fault (Figure 3b). Interpretation of deep reflectors in the crust provides the geometrical constraints on the position and extent of the lithological/ structural boundaries. 

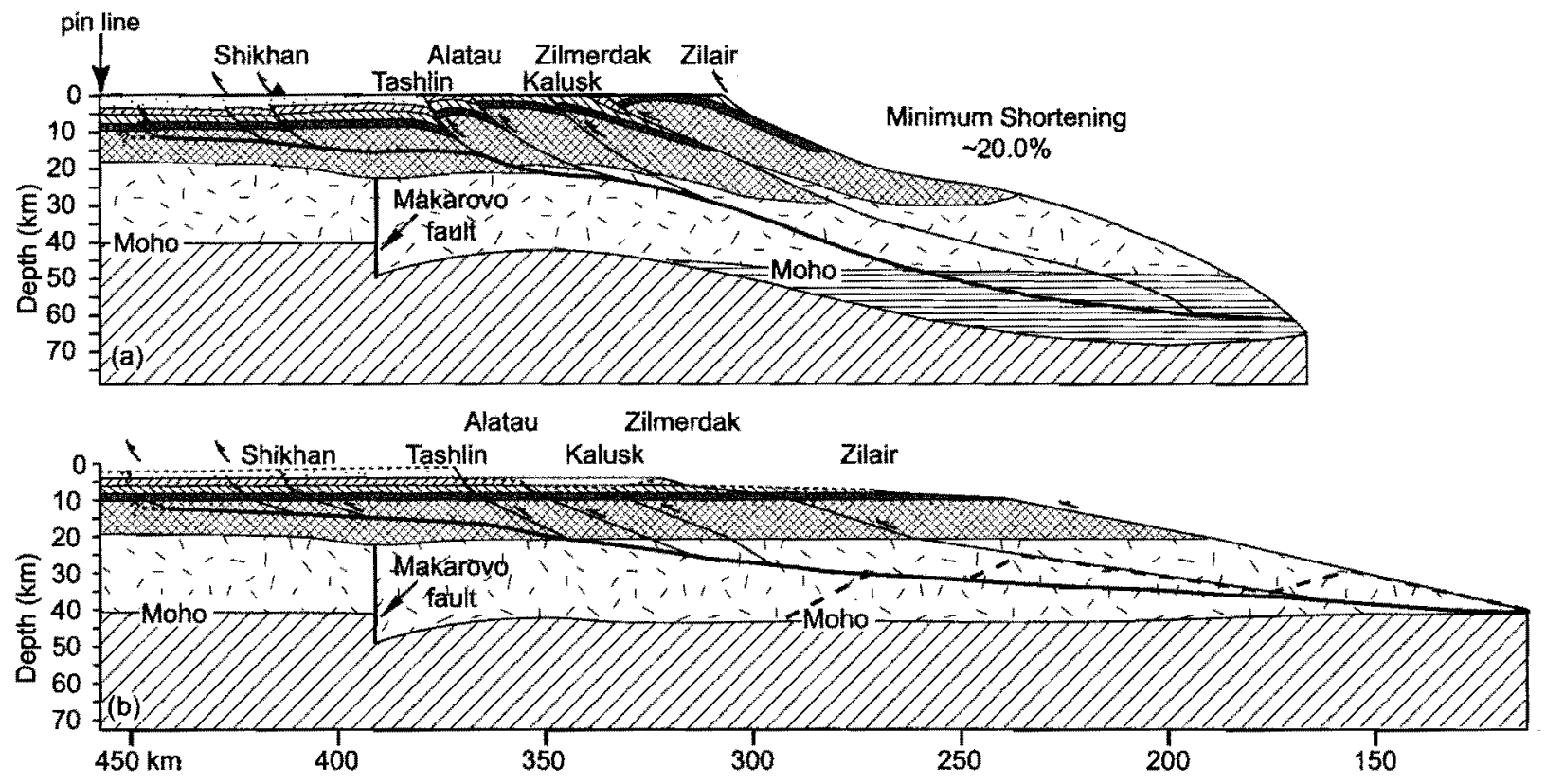

Figure 3. (a) Cross-section of the Southern Uralides foreland fold and thrust belt along the URSEIS profile, west of the Zilair fault. Dashed pattern below the Moho represents the eclogitized crustal root. (b) Crustal-scale restoration of the cross-section displayed in a. The master detachment is shown in bold line both in $a$ and $b$. Triangle shows the position of the Shikhan well. Legend the same as in Figure 2.

A whole-crust balance requires knowledge of the thickness of the crust prior to the deformation [Allmendinger et al., 1990]. A fairly reliable constraint on the crustal thickness beneath the East European platform along the URSEIS profile is provided by the Makarovo fault underneath the East European platform toward the western end of the Uralian Foreland fold and thrust belt [Diaconescu et al., 1998]. The Makarovo fault was interpreted to be a relic Precambrian (1.6 Ma) high angle fault that disrupts the Moho, but not the overlying Late Proterozoic sediments. Consequently, from this cross-cutting relationship, the Moho for this part of the orogen was interpreted to be Late Proterozoic or older in age (Figures 2 and 3) [Diaconescu et al., 1998]. Based on its preserved reflective character and the lack of a thick pile of Paleozoic or younger sediments, we interpret that the Moho depth $(42-45 \mathrm{~km})$ has not changed significantly beneath the East European margin during or after the Uralian deformation.

The fold thrust geometry of the Southern Uralides indicates that the dominant deformation mechanism of the fold and thrust belt appears to be fault propagation folding [Brown et al., 1997]. The crustal-scale restoration presented here (Figure 3) was based on the assumption that the stratigraphic thicknesses were maintained con- stant throughout the sedimentary section. Information on the thicknesses of the sedimentary layers was mainly provided by the Shikhan well that reached the Upper Riphean strata (Figure 3b) [Skripiy and Yunusov, 1989]. The Uralian and pre-Uralian deformation were not separated in the restoration. The sedimentary portion of the cross-section was bed-length balanced, whereas constant cross-sectional area balancing was used for the restoration of the crystalline basement while maintaining the slip on the faults constant. The pin line was placed at the western tip of the westernmost detected thrust (Figures $3 \mathrm{a}$ and $\mathrm{b}$ ).

The position and geometry of the master detachment (Figures $3 a$ and $b$ ) were interpreted on the basis of the seismic reflection character and agrees with some of the previous interpretations [Berzin et al., 1996]. The master detachment was located within the crystalline basement in the central-eastern side of the foreland fold and thrust belt and ramps up to $\sim 12-16 \mathrm{~km}$ with the Tashlin thrust, approaching the sedimentary portion of the section (Figures $3 \mathrm{a}$ and $\mathrm{b}$ ). West of the Zilmerdak thrust, the Upper and Middle Riphean rocks were involved in thrusting, suggesting that the basal detachment should be at least at the level of Middle Riphean in the section $(\sim 15 \mathrm{~km}$ depth). According to this interpretation 
(Figure 3), the Southern Uralides are underlain by a root at $\sim 53-70 \mathrm{~km}$ depth, which originated from continental material of the East European craton $(\sim 70 \%)$. This restoration of the Southern Uralides foreland fold and thrust belt west of the Zilar thrust predicts a shortening of $\sim 20 \%$ during the Uralian orogeny [Perez-Estaun et al., 1997]. However, since we only restored the Southern Uralide fold and thrust belt west of the Zilair fault due to the high complexity of the geology between this fault and the MUF, we interpret that this is an underestimated value.

\section{GEOPHYSICAL AND GEOLOGICAL DATA}

This study of the geodynamic evolution of the Southern Uralides draws heavily on a series of geophysical data and geological observations. Included in our study are (1) published near-vertical incidence/wideangle URSEIS seismic profile, (2) crustal-scale balanced cross-sections (3) published gravity, (4) topography, (5) published fission track data, and (6) published thermal modeling. Recent reprocessing of the URSEIS wideangle data [Carbonell et al., 1998, 2000] suggested that the seismically defined Moho, corresponding to an increase in the P-wave velocity from $\sim 7.2 \mathrm{~km} / \mathrm{s}$ to more than $8.0 \mathrm{~km} / \mathrm{s}$, occurs along a subhorizontal boundary at $\sim 53 \mathrm{~km}$ depth across the central portion of the orogen $(50-300 \mathrm{~km}$ in Figures $2 \mathrm{a}$ and $\mathrm{b})$. This boundary, picked on the basis of first arrivals of PmP waves on stacked versions of the wide-angle data, corresponds well with the downward disappearance of the well-defined Moho reflection on the eastern and western ends of the nearvertical incidence URSEIS profile $(\sim 50$ and $300 \mathrm{~km}$ in Figure 2a).

The gravity signature along the URSEIS profile (Figure $2 \mathrm{c}$ ) indicates a subdued ( $-50 \mathrm{mgal}$ ) long wavelength regional Bouguer gravity minimum across the axis of the Southern Uralides [Kruise and McNutt, 1988; Döring et al., 1997; Döring and Götze, 1999]. Accounting for previous structural interpretations of the URSEIS profile [Echtler and Hetzel, 1997] as well as velocity information from the wide-angle data, Döring and Götze [1999] performed a gravity modeling. Although not uniquely constrained, this model indicates high density material within the orogenic root to account for isostatic balance, with densities varying gradationally from 3.25 to $3.45 \mathrm{~g} / \mathrm{cm}^{3}$ (Figure $2 \mathrm{c}$ ). This model is in agreement with previous studies including a finite-difference flexural modeling approach for a simplified lithospheric model [Kruse and McNutt, 1988] which suggested that the lack of a significant negative Bouguer gravity anomaly above the Southern Uralides could be best explained by a sub- stantial subsurface load. The short wavelength Bouguer gravity maximum ( 10 mgal) observed between $150-300 \mathrm{~km}$ distance along URSEIS is consistent with the interpretation of high density material in the upper crust [Döring et al., 1997].

The Southern Uralides show a subdued topographic relief (Figure $2 \mathrm{a}$ ) for a non-extended orogen, with maximum elevations of $\sim 1600 \mathrm{~m}$ [Berzin et al., 1996; Piwowar et al., 1996]. Moreover, most of the topographic relief occurs in the foreland fold and thrust belt, west of the Main Uralian fault (260-400 km in Figure 2a), and is shifted westwards from the orogenic axis. The asymmetry of the topographic relief with respect to the crustal root suggests that the present-day topography is unrelated to the crustal thickness, and most likely represents remnant relief from the Paleozoic Uralian deformation [Piwowar et al., 1996]. Zircon fission-track ages for rocks exposed at the surface along the URSEIS profile [Seward et al., 1997] (Figure 2b) group at about $250 \mathrm{Ma}$ on both sides of the Main Uralian fault, suggesting that there has been little or no differential movement identifiable through fission-track analysis along this line since Triassic time. Similarly, apatite fission track ages range from $\sim 180$ to $210 \mathrm{Ma}$ in the Southern Uralian foreland fold and thrust belt, suggesting that little differential movement within the footwall of the Main Uralian fault occurred since Jurassic time. Although slightly older in the central part of the Magnitogorsk volcanic arc (Figure 2b) the apatite fission track ages confirm that there has been very little tectonic activity along the URSEIS transect including significant erosion or uplift recorded in fission track-data since Triassic time. The fission track data implies that the present topographic relief of the Southern Uralides has not significantly changed since Triassic time.

The central part of the Uralian orogen displays very low heat flow with typical values below $30 \mathrm{mWm}^{-2}$ [Kukkonen et al., 1997]. Geotherms calculated from heat flow density measured in boreholes along the central axis of the Southern Uralides indicate temperatures of $\sim 500-550^{\circ} \mathrm{C}$ at depths exceeding $50 \mathrm{~km}$. Since the Southern Uralides seem to have maintained their lithospheric structure and composition throughout their post-orogenic evolution, we believe that the presentday crustal scale geotherms may have not significantly changed since Late Paleozoic time.

\section{THE CASE FOR PHASE-CHANGE MOHO}

The role of the phase-change Moho to higher density eclogite facies rocks has been increasingly emphasized in the past years in relation to the geodynamic evolution 
of orogenic systems [e.g., Austrheim, 1991; Fountain et al., 1994a; Poli and Schmidt, 1997]. The temperature $\left(500-600^{\circ} \mathrm{C}\right)$ and pressure $(>10 \mathrm{kbar})$ conditions required for eclogite facies occurrences worldwide indicate that they form in subduction or overthickened crustal zones at depths exceeding 50 km [Austrheim, 1991; Spear, 1993; Fountain et al., 1994a; Hynes and Snyder, 1995; Schreyer and Stöckhert, 1997]. Although considered to be anhydrous garnet-clinopyroxene ( \pm quartz/coesite \pm rutile) assemblages [Poli and Schmidt, 1997], formation of eclogites may critically depend on the presence of fluids [Austrheim, 1991].

The bivergent geometry of the Southern Uralides from the URSEIS seismic profile (Figures $2 a-c$ ) and the slightly dipping Moho reflections toward the central part of the orogen imply that the crustal root was perhaps depressed to depths exceeding $\sim 53 \mathrm{~km}$ [Carbonell et al., 1998]. This depth favors the high pressure conditions required by the metamorphic phase-change to eclogite facies rocks [Austrheim, 1991]. In addition, the low geotherms $\left(-500-550^{\circ} \mathrm{C}\right)$ at the Moho as derived from modeling of the heat flow density [Kukkonen et al., 1997], if similar throughout the post-orogenic evolution, are favorable to eclogite formation within the Uralian root zone [Spear, 1993]. The subhorizontal wide-angle PmP Moho reflection beneath the main axis of the Southern Uralides corroborated by the lack of a clearly defined near-vertical incidence Moho reflection suggest that the Moho is a gradational boundary that was perhaps superimposed by a metamorphic phase-change developed across the structural fabrics produced during the Uralian orogeny. However, the diffuse (versus clearly defined, kilometers length coherent) zone of reflectivity within the Southern Uralides root $(175-300 \mathrm{~km}$ distance in Figure 2a) may suggest a mixture of rocks in different metamorphic phases i.e. mafic granulites and eclogites [Austrheim et al., 1997]. This would imply a partial metamorphic phase-change to higher density eclogites. Such mixing of metamorphic facies in the lower continental crust at similar depths was proposed in the Bergen Arc of western Norway where granulite and eclogite facies assemblages from the lowermost Caledonian continental crust were exposed at the surface [Boundy et al., 1992; Fountain et al., 1994a].

Eclogite facies rocks are known from laboratory studies to have elastic properties similar to mantle peridotites (P-wave velocity of 7.8 to $8.5 \mathrm{~km} / \mathrm{s}$; density of 3.1 to $3.6 \mathrm{~g} / \mathrm{cm}^{3}$ ) [Austrheim, 1991; Fountain et al., 1994a]. Despite the fact that eclogites derive from rocks of crustal origin [Kern and Richter, 1981; Austrheim, 1991; Mengel and Kern, 1992] such similarities in velocity and density make them practically indiscernible from mantle lithologies by seismic techniques. Large increases in P-wave velocity $(7.4$ to $8.3 \mathrm{~km} / \mathrm{s})$ and density $(3.0$ to $3.6 \mathrm{~g} / \mathrm{cm}^{3}$ ), resulting in an increase of $\sim 4-9 \%$ in acoustic impedance, were observed at the transition from granulite to eclogite facies rocks exposed in the Bergen Arcs of western Norway [Fountain et al., 1994b]. The lack of a reflective Moho boundary was interpreted to be a consequence of eclogite facies metamorphism in some continent-continent collision zones, including the Central Alps [Laubscher, 1990; Austrheim, 1991] and the Trans-Hudson orogen [Baird et al., 1995]. According to Furlong and Fountain [1986], the juxtaposition of eclogite facies rocks with peridotitic mantle material would produce very small reflection coefficients that are hardly observable on seismic data.

A significant constraint in support of our proposed model for eclogitization of the Southern Uralian crustal root is provided by balanced restoration of the Uralian crust. The crustal-scale restoration of the foreland fold and thrust belt along the URSEIS profile provides support for the crustal origin for the material at $\sim 53-70 \mathrm{~km}$ depth beneath the central part of the orogen (horizontal line pattern in Figures $2 b$ and $3 a$ ). We interpret this portion of the section to be the crustal root, despite its position below the inferred Moho from the wide-angle data, and thus making the Moho a phase-change boundary. From the crustal-scale restoration (Figure 3) there is an indication that the Southern Uralides root originated primarily from continental material belonging to the East European craton $(\sim 70 \%)$, and specifically lower crustal rocks of probable mafic granulitic composition. This interpretation is somewhat different from other recent studies [Stadtlander et al., 1999] that interpreted the higher density and velocity rocks of the Southern Uralian root as remnant oceanic crust or a mix of oceanic crust and mantle material. Compared to other orogens like the Alps where mass balance analysis suggested deficit of crustal material interpreted to have been recycled into the mantle [Laubscher, 1990], we suggest that the Southern Uralides have preserved their crustal root, but as higher density eclogite facies rocks contradicting some recent models which argue otherwise [Leech, 2001]. Therefore, the base of the root (Figures 2 and 3) is deeper $(\sim 70 \mathrm{~km})$ than it was previously interpreted $(\sim 55-60 \mathrm{~km})$ [Carbonell et al., 1996; Knapp et al., 1996; Steer et al., 1998] due to the higher velocity eclogitic material $(7.6-8.2 \mathrm{~km} / \mathrm{s})$ [Carbonell et al., 1998]. The total shortening calculated for the Southern Uralides foreland fold and thrust belt is $\sim 20 \%$, slightly larger than previously estimated $(\sim 17 \%)$ from shallow crustal restoration [Brown et al., 1997; Perez-Estaun et al, 
1997]. This relatively reduced shortening was previously interpreted as one of the causes for the long-lived orogenic structure of the Southern Uralides [e.g., Berzin et al., 1996].

There have been several models of the subdued longwavelength gravity signature over the Uralides [Kruse and McNutt, 1988; Döring et al., 1997; Döring and Götze, 1999]. The flexural model proposed by Kruse and McNutt [1988] argued for the presence of a subsurface crustal load to account for the subdued ( $-50 \mathrm{mgal}$; Figure 2c) negative Bouguer gravity anomaly above the central part of the orogen. More recently, Döring and Götze [1999] modeled the gravity field across the URSEIS profile (Figure 2c), and they suggested the presence of high density rocks $\left(3.25-3.45 \mathrm{~g} / \mathrm{cm}^{3}\right.$; Figure 2c) within the root. Therefore, this discrepancy of a lack of a significant negative gravity anomaly across a preserved, non-extended orogen, could be accounted for, if in fact, the original root has been transformed into a higher density eclogite consistent with the model proposed in this paper and the densities derived from the gravity modeling [Döring and Götze, 1999; Figure 2c). The Magnitogorsk volcanic arc in the hanging wall of the Main Uralian fault, with high density $\left(-3.0 \mathrm{~g} / \mathrm{cm}^{3}\right)$ rocks, appears to account for the short wavelength local Bouguer gravity maximum ( $\sim 10 \mathrm{mgal})$ across the axis of the orogen [Döring and Götze, 1999].

Maximum topographic elevations across the Uralides indicate relatively low $(\sim 1600 \mathrm{~m})$ relief for a nonextended orogen, implying that the compensation mechanism is not related exclusively to the crustal thickness. We interpret the lack of significant topographic relief across the Southern Uralides as additional evidence for major post-orogenic changes within the root. The short wavelength topography in the Southern Uralian foreland fold and thrust belt appears to be mainly a result of the shallow geologic structure and lithology, with no evident correlation to the crustal root. Since the Southern Uralides still preserve the Paleozoic structure and escaped orogenic collapse, we interpret this "lack" of orogenic root as in fact a metamorphic phase-change to higher density eclogite facies rocks. Moreover, the asymmetry in the gravity about the topographic peak (Figures $2 \mathrm{a}$ and c) provides additional evidence that the mountain load is not supported exclusively by local thickening of the crust [Kruse and McNutt, 1988]. This may serve as a substantiation for additional load in the lower crust provided by higher density eclogites. Furthermore, the zircon and apatite fission-track data suggest minimum cooling ages for rocks exposed at the surface along the URSEIS section of Late Triassic-Early Jurassic (Figure 2b). This analysis corroborated by preservation of surficial geologic features at low metamorphic grade [Echtler et al., 1996; Echtler and Hetzel, 1997] in the footwall of the Main Uralian fault suggest that very little tectonic activity, including uplift and erosion, has been recorded in the post-tectonic development of the Southern Uralides. Thus, we put forth a model that the inferred metamorphic phase change to higher density eclogite facies rocks of the Southern Uralian crustal root perhaps served to stabilize the orogenic architecture, preventing it from orogenic collapse. This geodynamic setting is very different from other orogenic systems, where the eclogitization of the orogenic roots caused post-orogenic collapse and extension [Austrheim, 1991; Laubscher, 1990; Baird et al., 1995].

The timing we propose for the eclogitization of the Southern Uralides lower crust bears on the interpretation of zircon and apatite fission-track data and the position of the Moho relative to the Uralian structures. The fairly flat Moho at $\sim 53 \mathrm{~km}$ depth from the URSEIS wide-angle data (Figure 2b) overprints the Uralian orogenic fabric [Carbonell et al., 1998], and consequently it must be younger than Uralian. The zircon and apatite fission-track data [Seward et al., 1997] indicate that the cooling ages for rocks exposed now at the surface cluster in the Late Triassic to Early Jurassic time (200-260 Ma), indicating that no significant erosion or uplift have occurred in the Southern Uralides since that time. Therefore, we propose that the eclogitization of the Uralian crustal root perhaps occurred at or after the end of the collisional process between Late Triassic and Early Jurassic time.

The presence of the high-grade metamorphic Maksyutov Complex in the footwall of the Main Uralian fault implies that we cannot rule out the occurrence of eclogite facies metamorphism in the lower crust of the Southern Uralides at earlier stages of Uralian orogenic deformation. There is independent geologic evidence of continental collision in the Late Precambrian, which may have resulted in eclogite formation [Gee et al., 1996; Giese et al., 1999]. In addition, there are eclogitic rocks exposed at the surface and preserved in the high-grade metamorphic Maksyutov Complex [Beane et al., 1995; Lennykh et al., 1995, 1997; Leech and Stockli, 2000]. These eclogites have been dated as Devonian in age (377-384 Ma) based on U-Pb decay ages of rutile within the mafic eclogite [Beane et al., 1995, 1997; Beane and Conelly, 2000]. From apatite fission track data, Leech and Stockli [2000] proposed that the Maksyutov Complex was exhumed in Early Permian time $(\sim 300 \mathrm{Ma})$, therefore it appears to be very little related to our proposed Late Triassic to Early Jurassic 
eclogite facies assemblages within the Southern Uralian lower crust.

The eclogite facies phase change appears to require fluids to trigger the reaction kinetics, in addition to suitable pressure and temperature conditions [Austrheim, 1987; Fountain et al., 1994b]. Study of eclogites from the Bergen Arc suggested that the amount of eclogite versus granulite in the lower crust is dependent primarily on fluid access and existing deformation rather than only pressure, temperature, and rock composition. Similarly, research on the Precambrian granulites of the Western Gneiss region of Norway indicated that granulites may remain metastable in the eclogite field if water is not available [Austrheim et al., 1997]. Although highly speculative, pathways for fluids in the Southern Uralides might have been provided by a later westward subduction to the east of the Main Uralian fault along either the Kartaly fault or the structures further to the east (Figure 2b) [Echtler and Hetzel, 1997]. The presence of early Permian Chebik granites at the surface within the Uralian hinterland (Figure 2b) [Echtler et al., 1996; Steer et al., 1998] may suggest that the underlying Kartaly fault may be younger than early Permian, and implicitly younger than the MUF.

\section{GEODYNAMIC EVOLUTION OF THE SOUTHERN URALIDES IN RELATION TO OTHER OROGENS}

Tectonic evolution of the Southern Uralides stands in apparent contrast to other orogens where either delamination of the lower crust and uppermost mantle or significant subsidence were interpreted to result from eclogitization of crustal roots (Figure 4) [Austrheim, 1991; Laubscher, 1990; Baird et al., 1995]. In the Early Tertiary Alps (Figure 4a), the proposed eclogitized European crustal root is thought to be depressed to depths in excess of $60 \mathrm{~km}$ based on deep seismic reflection data [Laubscher, 1990]. The metamorphic phase-change to higher density eclogites was suggested to occur concurrently with the collision between the European and African plates. The eclogitization of the lower crust, the indentation of the European crust by wedges of the African crust protruding northwards beneath the Alps as well as the ultramafic composition of the protolith were interpreted as triggering factors for the delamination of the European lower crust and lithospheric mantle [Frei et al., 1989; Bousquet et al., 1997]. Among the strongest evidence for the subduction of the European continental lithosphere and delamination of the Alpine crustal root was provided by material balance calculations [Laubscher, 1989] and tomographic studies
[Spakman et al., 1993]. Unlike the model proposed for the Southern Uralides, the estimated shortening in the Alps exceeds the length of the restored section of the Alpine foreland fold and thrust belt, and delamination of the Alpine crustal root was interpreted to account for this deficit.

Some of the best studied orogenic belts, particularly in relation to deep crustal processes, is the early Paleozoic Caledonian belt. The post-orogenic evolution of the Scandinavian Caledonides indicates a similar tectonic progression with the Alps, but the Caledonides are probably in a more advanced geodynamic setting having already experienced orogenic collapse [Austrheim, 1987; Andersen et al., 1991; Austrheim, 1991; Boundy et al., 1992; Fountain et al., 1994a; Austrheim et al., 1997]. In the Scandinavian Caledonides, Precambrian granulite facies rocks were interpreted to have undergone fluidcontrolled eclogitization on a regional scale, which conceivably destabilized the isostatic equilibrium due to a much heavier root. As a result, the Caledonides perhaps dropped their root, which triggered subsequent collapse and extension.

Eclogitization of orogenic roots has also been proposed for Proterozoic age orogenic belts such as the Trans-Hudson orogen of North America (Figure 4c) [Baird et al., 1995, 1996]. Here, eclogitization of the Hudsonian crustal root was proposed as a much later event in the orogenic development, some $\sim 1.2 \mathrm{Ga}$ after the termination of the collisional process. From deep seismic reflection profiling, the eclogitization of the Trans-Hudson root was interpreted as a mechanism of triggering post-orogenic subsidence of the overlying upper crust, resulting in the formation of the Williston sedimentary basin [Baird et al., 1995, 1996].

Quite a different evolution of the lower crust characterizes the Tibetan Plateau where in fact retrogression of eclogite to granulite facies rocks was proposed as a mechanism to cause large-scale uplift without surface shortening [Le Pichon et al., 1997]. An alternative model for the high elevations of the Himalayas was proposed by Henry et al. [1997] who suggested that the eclogitization of the underthrust Indian lower crust at $\sim 75 \mathrm{~km}$, as opposed to $\sim 55 \mathrm{~km}$ for the Alps, enabled the mountain belt to maintain its higher average altitude $(5 \mathrm{~km})$. This latter study proposed that the depth of the granulite to eclogite transition may play an important role in the geodynamic evolution of the orogens.

The model put forth in this paper certainly does not provide all of the answers with regard to the post-tectonic stabilization of the Southern Uralides. Yet, it is widely accepted that the Southern Uralides have preserved their collisional architecture for more than $250 \mathrm{Ma}$, and our 

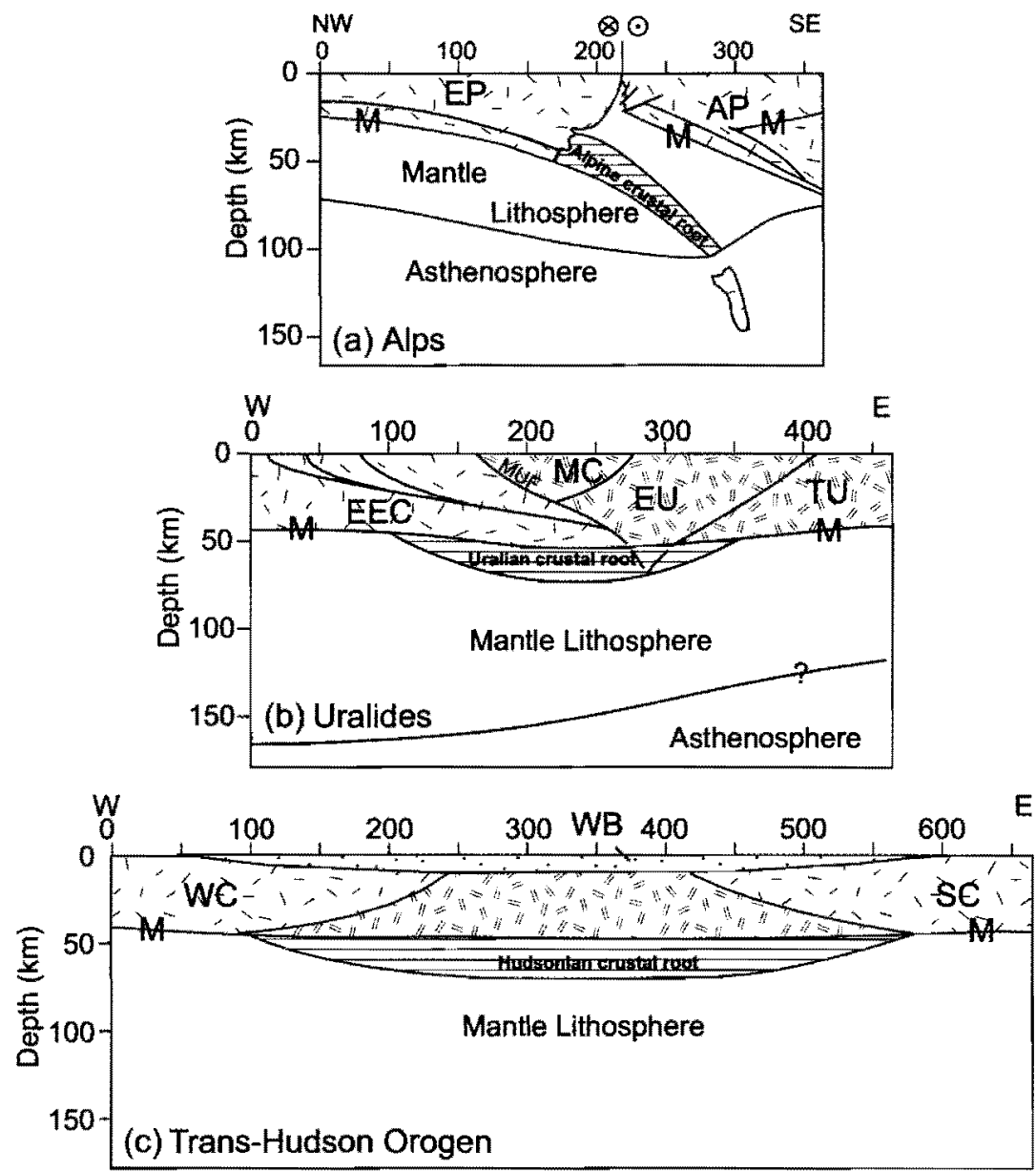

Figure 4. Contrasting geodynamic models resulting from the eclogitization of orogenic roots: (a) the Alps (delamination), after Marchant and Stampfli (1997). M - the Moho, EC - European Plate, AP - Adriatic plate. (b) the Uralides (stabilization). EEC - East European Craton, EU - East Uralian zone, MC - Maksyutov complex, TU - Trans Uralian zone, MUF - Main Uralian fault; and (c) the Trans-Hudson orogen (subsidence), after Baird et al. (1995). WB - Williston Basin, WC - Wyoming Craton, SC - Superior Craton. Horizontal line pattern shows the portion of the continental crust interpreted as eclogite-facies rocks.

model presents a possible scenario for this anomaly. The metamorphic phase-change of the Southern Uralian crustal root into higher density eclogite facies rocks possibly caused the stabilization and preservation of the Late Paleozoic Uralian orogenic architecture, and built an isostatically balanced system that restrained the eclogitic crustal root from sinking into the mantle. Based on this study, we further suggest that the timing of the eclogitization of crustal roots may play a significant role in the geodynamic evolution of the orogens. This interpretation adds a new possible explanation to previous attempts to decipher the causes for stabilization and preservation of the Uralian orogen, including (1) abundance of island ares or/and (2) incomplete or "arrested" collisional process [Berzin et al., 1996]. While this interpretation is in agreement with some of the previous models put forth for the geodynamic evolution of the Southern Uralides [Artyushkov et al., 2000], it contradicts others [Leech, 2001] that suggested that the Southern Uralides orogenic root has not undergone metamorphic phase-change to higher density eclogites.

There is still a question why the Uralides did not loose their heavy root as proposed for other orogenic belts [e.g., Platt and England, 1994; Bousquet et al., 1997; Marotta et al., 1998], or alternatively, why the eclogitic root did not retrogress to higher temperature granulites. A possible scenario is that the Southern Uralian root is made of lighter andesitic eclogites as opposed to heavier 
gabbroic eclogites favoring gravitational equilibrium in contrast to gravitational instability and delamination [Bousquet et al., 1997] although this model stays at odds with the lack of abundance reflectivity at the lower crustal levels beneath the axis of the orogen. However, the geotherms at $\sim 70 \mathrm{~km}$ depth beneath the central part of the Southern Uralides are below $700^{\circ} \mathrm{C}$ [Kukkonen et al., 1997], indicating that the root is within the eclogite stability field, and too low to allow retrogression to lower grade granulites [Henry et al., 1997]. However, the timing of eclogitization, perhaps driven by the availability of fluid to flux the reaction kinetics, may be as important as the depth of the metamorphic phase-change.

\section{CONCLUSIONS}

Crustal-scale restoration of the Southern Uralide fold and thrust belt corroborated by wide-angle/nearvertical incidence URSEIS seismic profile, gravity, topography, fission track data, and thermal modeling provide the basis for a model involving metamorphic phase-change to higher density eclogite facies assemblages within the orogenic root. Our model predicts that the Southern Uralian lower crust should be eclogitized at a depth of $\sim 53-70 \mathrm{~km}$ where the wide-angle PmP arrivals indicate an increase of the $P$-wave velocity to $\sim 8.0 \mathrm{~km} / \mathrm{s}$ and the near-vertical incidence seismic reflection Moho is lost due to presumably mantle-like density and velocity. From the crustal scale restoration, we predict that $\sim 70 \%$ of the existent Southern Uralides root originates from continental crust of East European affinity, and only $30 \%$ derives from accreted terranes west of the Main Uralian fault. The loss of the Moho reflection character could be interpreted that massive eclogitization occurred within the Southern Uralian root to raise the velocity and density to mantle values. This would further imply that sufficient water was released in the crust to allow massive eclogitization, possibly from adjacent west-dipping subduction zone of the accreted terranes in the Uralian hinterland.

Earlier studies [Döring and Götze, 1999; Carbonell et al., 2000] suggested the presence of a high density body at the Southern Uralian crust/mantle boundary. Here, we do not only provide a more quantitative model in support of the eclogitization of a substantial crustal root, but we suggest that this process occurred between the Late Triassic and Early Jurassic time, and may have served to stabilize and preserve the collisional orogenic structure. The Southern Uralides represent a unique case for studying the long-term stability of orogenic systems, being the only Paleozoic mountain belt which escaped post-orogenic collapse. In addition to previous studies
[Austrheim et al., 1997; Henry et al., 1997] which argued that the depth of the granulite to eclogite transition may play a significant role in the orogenic evolution, we suggest that the timing of eclogitization may be an important factor in the geodynamic development of orogenic systems. The inferred post-collisional eclogitization of the Southern Uralides lower crust perhaps built an isostatically balanced orogenic system, with subdued topography, and served to stabilize the orogenic architecture.

Formation of eclogite facies rocks in overthickened orogenic roots and the resulting geodynamic processes are still under debate. It has been suggested that formation of eclogites at the crust-mantle boundary triggered delamination of the lower crust and upper mantle in the Alps [Laubscher, 1990] or delamination followed by postorogenic collapse in the Caledonides [Austrheim, 1991], or only subsidence of the overlying upper crust in the Trans-Hudson orogen [Baird et al., 1995, 1996]. Unlike these other models of eclogitization of the orogenic roots (Figure 4), the Southern Uralides appear to be an intermediate case in which there is no evidence for either delamination or subsidence of the overlying upper crust. Conversely, examples from the Tibetan Plateau [Henry et al., 1997; Le Pichon et al., 1997], the Variscan granulites of the French Massif Central [Pin and Vielzeuf, 1983; Mercier et al., 1991], and eastern Australia [Smith, 1982] suggested that retrogression from eclogite to granulite facies rocks due to the gradual increase in temperature could be a mechanism of triggering epeirogenic events including regional scale uplift. The present-day low temperatures in the Southern Uralides at $-70 \mathrm{~km}$ $\left(<700^{\circ} \mathrm{C}\right)$ [Kukkonen et al., 1997] are within the eclogite stability field, well below the stability temperatures for granulite facies rocks $\left(\sim 800^{\circ} \mathrm{C}\right)$, preventing the occurrence of retrogression to granulites. Since it is widely accepted that eclogites commonly have densities higher than the surrounding mantle peridotites [Mengel and Kern, 1992] there is still an open question why the Southern Uralides root has not recycled yet into the mantle [e.g., Platt and England, 1994; Dewey, 1998].

The Southern Uralides represent yet another example that orogenic loads could be supported by density heterogeneities in the lower crust or upper mantle rather than thickening of the crust or lateral density variations. However, in contrast with the compensation model proposed for the Sierra Nevada, where the high elevations may be supported by low density bodies in the upper mantle [e.g., Ducea and Saleeby, 1996; Jones and Phinney, 1998], we suggest that the low elevations of the Southern Uralides resulted from high density material in the upper mantle, specifically eclogite facies assemblages that perhaps served to stabilize the orogen. 
Acknowledgments. This work benefited from funding provided by National Science Foundation grant EAR9418251, and formed part of the Ph.D. thesis research of C. C. Diaconescu while at Cornell University. We thank all of the participants in the URSEIS project for their contributions to its success. L. D. Brown, R. W. Allmendinger, D. N. Steer, and E. Sandvol helped to shape our ideas through engaging discussions. J. McBride and D. Fountain provided useful insight on an earlier version of the manuscript. Special thanks are due to D. Brown, C. Hurich, and H. Austrheim for their helpful comments and thorough reviews of the manuscript.

\section{REFERENCES}

Ahrens, T. J. and G. Schubert, Gabbro-eclogite reaction rate and its geophysical significance, Rev. of Geophys. Space Phys., 13, 383-400, 1975.

Allmendinger, R. W., D. Figueroa, D. Snyder, J. Beer, C. Mpodozis and B. L. Isacks, Foreland shortening and crustal balancing in the Andes at $30^{\circ} \mathrm{S}$ latitude, Tectonics, 9, 789-809, 1990.

Andersen, T. B., B. Jamtveit, J. F. Dewey and E. Swensson, Subduction and eduction of continental crust; major mechanisms during continent-continent collision and orogenic extensional collapse, a model based on the South Norwegian Caledonides, Terra Nova, 3, 303-310, 1991.

Artyushkov, E. V., M. A. Baer, P. A. Chekhovich and N. A. Morner, The Southern Urals. Decoupled evolution of the thrust belt and its foreland: a consequence of metamorphism and lithospheric weakening, Tectonophysics, 320, 271-310, 2000.

Austrheim, H., Eclogitization of lower crustal granulites by fluid migration through shear zones, Earth Planet. Sci. Lett., 81, 221-232, 1987.

Austrheim, H., Eclogite formation and dynamics of crustal roots under continental collision zones, Terra Nova, 3, 492-499, 1991.

Austrhein, H., M. Erambert and A. K. Engvik, Processing of crust in the root of the Caledonian continental collision zone; the role of eclogitization, Tectonophysics, 273, 129-153, 1997.

Baird, D. J., J. H. Knapp, D. N. Steer, L. D. Brown and K. D. Nelson, Upper-mantle reflectivity beneath the Williston basin, phase change Moho, and the origin of the intracratonic basins, Geology, 23, 431-434, 1995.

Baird, D. J., K. D. Nelson, J. H. Knapp, J. J. Walters and L. D. Brown, Crustal structure and evolution of the TransHudson orogen: Results from seismic reflection profiling, Tectonics, 15, 416-426, 1996.

Beane, R. J. and J. N. Connelly, ${ }^{40} \mathrm{Ar} /{ }^{39} \mathrm{Ar}, \mathrm{U}-\mathrm{Pb}$ and $\mathrm{Sm}-\mathrm{Nd}$ constraints on the timing of metamorphic events in the Maksyutov Complex, Southern Ural Mountains, J. Geol. Soc. London, 157, 811-822, 2000.

Beane, R. J., Petrologic evolution and geochronologic constraints for high-pressure metamorphism in the Maksyutov
Complex, South Ural mountains, Ph.D. thesis, Stanford University, Stanford, 1997.

Beane, R. J., J. G. Liou, R. G. Coleman and M. J. Leech, Petrology and retrograde P-T path for eclogites of the Maksyutov Complex, Southern Ural Mountains, Russia, The Island Arc, 4, 254-266, 1995.

Berzin, R., O. Oncken, J. H. Knapp, A. Pérez-Estaún, T. Hismatulin, N. Yunusov and A. Lipilin, Orogenic evolution of the Ural mountains: results from an integrated seismic experiment, Science, 274, 220-221, 1996.

Boundy, T. M., D. M. Fountain and H. Austrheim, Structural development and petrofabrics of eclogite facies shear zones, Bergen arcs, western Norway; implications for deep crustal deformational processes, J. Metamorph. Geol., 10, 127-146, 1992.

Bousquet, R., B. Goffe, P. Henry, X. Le Pichon and C. Chopin, Kinematic, thermal and petrological model of the Central Alps; Lepontine metamorphism in the upper crust and eclogitization of the lower crust, Tectonophysics, 273, 105-127, 1997.

Brown, D., V. Puchkov, J. Alvarez-Marron and A. PerezEstaun, The structural architecture of the footwall to the Main Uralian Fault, southern Urals, Earth Sci. Rev., 40, 125-147, 1996.

Brown, D., V. Puchkov, J. Alvarez-Marron and A. PerezEstaun, Preservation of a subcritical wedge in the south Urals foreland thrust and fold belt, J. Geol. Soc., London, 154, 593-596, 1997.

Brown, D., C. Juhlin, J. Alvarez Marron, A. Perez-Estaun and A. Oslianski, Crustal-scale structure and evolution of an arc-continent collision zone in the Southern Urals, Russia, Tectonics, 17, 158-171, 1998.

Carbonell R., A. Perez-Estaun, J. Gallart, J. Diaz, S. Kashubin, J. Mechie, R. Stadtlander, A. Schultze, J. H. Knapp and A. Morozov, Crustal root beneath the Urals: Wide-angle seismic evidence, Science, 274, 222-224, 1996.

Carbonell, R., D. Lecerf, M. Itzin, J. Gallart and D. Brown, Mapping the Moho beneath the Southern Urals with Wide-angle Reflections, Geophys. Res. Lett., 25, 4229-4232, 1998.

Carbonell, R., J. Gallart, A. Perez-Estaun, J. Diaz, S. Kashubin, J. Mechie, F. Wenzel and J. H. Knapp, Seismic wide-angle constraints on the crust of the Southern Urals, J. Geophys. Res., 105, 13,755-13,777, 2000.

Cook, F. A., D. S. Albaugh, L. D. Brown, S. Kaufman, J. E. Oliver and R. D. Hatcher, Jr., Thin-skinned tectonics in the crystalline southern Appalachians; COCORP seismicreflection profiling of the Blue Ridge and Piedmont, Geology, 7, 563-567, 1979.

Dahlstrom, C. D. A., Structural geology in the eastern margin of the Canadian rocky mountains, Bull. Canadian Petrol. Geol., 18, 332-406, 1970.

Dewey, J. F., Extensional collapse of orogens, Tectonics, 7, 1123-1139, 1988.

Dewey, J. F., P. D. Ryan and T. B. Andersen, Orogenic uplift and collapse, crustal thickness, fabrics and meta- 
morphic phase changes; the role of eclogites in Magmatic processes and plate tectonics, edited by $H . M$. Prichard, T. Alabaster, N. B. W. Harris and C. R. Neary, Geological Society Special Publications, 76, 325$343,1993$.

Diaconescu, C. C., J. H. Knapp, L. D. Brown, D. N. Steer and M. Stiller, Precambrian Moho offset and tectonic stability of the East European platform from the URSEIS deep seismic profile, Geology, 26, 211-214, 1998.

Dobretsov, N. L., V. S. Shatsky, R. G. Coleman, V. I. Lennykh, P. M. Valizer, J. Liou, R. Zhang and R. J. Beane, Tectonic setting and petrology of ultrahigh-pressure metamorphic rocks in the Maksyutov Complex, Ural Mountains, Russia, Int. Geol. Rev., 38, 136-160, 1996.

Döring, J., H. J. Götze and M. K. Kaban, Preliminary study of the gravity field of the Southern Urals along the URSEIS '95 seismic profile, Tectonophysics, 276, 49-62, 1997.

Döring, J. and H. J. Götze, The isostatic state of the southern Urals crust, Geol. Rundsch, 87, 500-510, 1999.

Ducea, M. N. and J. B. Saleeby, Buoyancy sources for a large, unrooted mountain range, the Sierra Nevada, California; evidence from xenolith thermobarometry, $J$. Geophys. Res., 101, 8229-8244, 1996.

Druzhinin, V, S., S. N. Kashubin, S. V. Avtoneev and V. M. Rybalka, New data on deep structure of the Southern Urals according to results of investigations on the Troitsk DSS profile, Soviet Geol. Geophys., 29, 79-82, 1988.

Druzhinin, V. S., S. V. Avtoneev, S. N. Kashubin and V. M. Rybalka, New data on the deep structure of the northern area of the Southern Urals in section of the Taratash DSS profile, Soviet Geol. Geophys., 31, 113-116, 1990.

Echtler, H. P., M. Stiller, F. Steinhoff, A. Suleimanov, J. H. Knapp and J. Alvarez-Marron, URSEIS "95 Crustal architecture of the southern Urals by vibroseis CMP-profiling, Science, 274, 224-226, 1996.

Echtler, H. P. and R. Hetzel, Main Uralian thrust and Main Uralian normal fault; nonextensional Paleozoic high-P rock exhumation, oblique collision, and normal faulting in the Southern Urals, Terra Nova, 9, 158-162, 1997.

Fountain, D. M., T. M. Boundy, H. Austrheim and P. Rey, Eclogite-facies shear zones - deep crustal reflectors, Tectonophy'sics, 232, 411-424, 1994a.

Fountain, D. M., P. Rey and H. Austrheim, Seismic velocities across the garnet granulite-eclogite facies transition, Eos, Trans., Am. Geophys. Union, 75 (44, Suppl.), 676 pp. $1994 \mathrm{~b}$.

Frei, W., P. Heitzmann, P. Lehner, S. Muller, R. Olivier, A. Pfiffner, A. Steck and P. Valasek, Geotraverses across the Swiss Alps, Nature, 340, 1989.

Furlong, K. P. and D. M. Fountain, Continental crustal underplating; thermal considerations and seismic-petrologic consequences, J. Geophys. Res., 91, 8285-8294, 1986.

Gee, D. G., M. Beckholmen, M. Friberg, A. N. Glushkov and V. Sokolov, Baikalian-age structural control of Uralian tectonics-evidence from the Middle Urals: Scientific Pro- gram and Abstracts, EUROPROBE Workshop Uralides Session, Granada, Spain, 7 pp., 1996.

Giese U, U. Glasmacher, V. I. Kozlov, I. Matenaar, V. N. Puchkov, L. Stroink, W. Bauer, S. Ladage and R. Walter, Structural framework of the Bashkirian anticlinorium, SW Urals, Geol. Rund., 87, 526-544, 1999.

Hamilton, W., The Uralides and the motion of the Russian and Siberian platforms, Geol. Soc. of Amer. Bull., 81, 2553-2576, 1970.

Henry, P., X. Le Pichon and B. Goff, Kinematic, thermal and petrological model for the Himalayas: constraints related to metamorphism within the underthrust Indian crust and topographic elevation, Tectonophysics, 273, $31-56,1997$.

Henstock, T. J., A. Levander, C. M. Snelson, G. R. Keller, K. C. Miller, S. H. Harder, A. R. Gorman, R. M. Clowes, M. J. A. Burianyk and E. D. Humphreys, Probing the Archean and Proterozoic lithosphere of western North America, GSA Today, 8, 1-5, 1998.

Hetzel, R., Geology and geodynamic evolution of the high-P/ low-T Maksyutov Complex, southern Urals, Russia, Geol. Rundsch., 87, 577-588, 1999

Hetzel, R., H. P. Echtler, W. Seifert, B. A. Schulte and K. S. Ivanov, Subduction- and exhumation-related fabrics in the Paleozoic high-pressure/low-temperature Maksyutov Complex, Antingan area, Southern Urals, Russia, GSA Bulletin, 110, 916-930, 1998 .

Hynes, A. and D. B. Snyder, Deep-crustal mineral assemblages and potential for crustal rocks below the Moho in the Scottish Caledonides, Geophys. J. Int., 123, 323-339, 1995.

Jones, C. H., H. Kanamori and S. W. Roecker, Missing roots and mantle "drips"; regional $\mathrm{P}$ (sub $\mathrm{n}$ ) and teleseismic arrival times in the southern Sierra Nevada and vicinity, California, I. Geophys. Res., 99, 4567-4601, 1994.

Jones, C. H. and R. A. Phinney, Seismic structure of the lithosphere from teleseismic converted arrivals observed at small arrays in the southern Sierra Nevada and vicinity, California, J. Geophys. Res., 103, 10,065-10,090, 1998.

Juhlin, C., J. H. Knapp, S. Kashubin and M. Bliznetsov, Crustal evolution of the middle Urals based on seismic reflection and refraction data, Tectonophysics, 264, 21-34, 1996.

Kern, H. and A. Richter, Temperature derivatives of compressional and shear wave velocities in crustal and mantle rocks at $6 \mathrm{kbar}$ confining pressure, $J$. Geophys., 49, 47-56, 1981.

Knapp, J. H., C. C. Diaconescu, M. A. Bader, V. B. Sokolov, S. N. Kashubin and A. V. Rybalka, Seismic reflection fabrics of continental collision and post-orogenic extension in the Middle Urals, central Russia, Tectonophysics, 288, 115-126, 1998.

Knapp, J. H., D. N. Steer, L. D. Brown, R. Berzin, A. Suleimanov, M. Stiller, E. Lüschen, D. Brown, R. Bulgakov, S. N. Kashubin and A. V. Rybalka, Lithosphere-scale seismic image of the southern Urals from explosion-source reflection profiling, Science, 274, 226-227, 1996. 
Kruse, S. E. and M. McNutt, Compensation of Paleozoic orogens; a comparison of the Urals to the Appalachians, Tectonophysics, 154, 1-17, 1988.

Kukkonen, I. T., I. V. Golovanova, Y. V. Khachay, V. S. Druzhinin, A. M. Kosarev and V. A. Schapov, Low geothermal heat flow of the Urals fold belt - implication of low heat production, fluid circulation or palaeoclimate?, Tectonophysics, 276, 63-85, 1997.

Laubscher, H., The problem of the Moho in the Alps, Tectonophysics, 182, 9-20, 1990.

Leech, M., Arrested orogenic development; eclogitization, delamination and tectonic collapse, Earth Planet. Sci. Lett., $18,149-159,2001$

Leech, M. L. and F. Stockli, The late exhumation history of the ultrahigh-pressure Maksyutov Complex, South Ural mountains, from new apatite fission-track data, Tectonics, $19,153167,2000$

Lennykh, V. I., P. M. Valizer, R. Beane, M. Leech and W. G. Ernst, Petrotectonic evolution of the Maksyutov Complex, Southern Urals, Russia: Implications for ultrahigh-pressure metamorphism, Int. Geol. Rev, 37, 584-600, 1995.

Le Pichon, X., P. Henry and B. Goffe, Uplift of Tibet; from eclogites to granulites; implications for the Andean Plateau and the Variscan belt, Tectonophysics, 273, 57-76, 1997.

Meissner, R., T. Wever and R. Bittner, Results of DEKORP 2-S and other reflection profiles through the Variscides, Geophys. J. Royal Astronom. Soc., 89, 319-324, 1987.

Marchant, R. H. and G. M. Stampfli, Crustal and lithospheric structure of the Western Alps; geodynamic significance, In Results of NRP 20; Deep Structure of the Swiss Alps, edited by $\mathrm{O}$. A. Pfiffner, P. Lehner, P. Heitzman, S. Mueller and A. Steck, pp. 326-337, 1997.

Marotta, A. M., M. Fernandez and R. Sabadini, Mantle unrooting in collisional settings, Tectonophysics, 296, 31-46, 1998.

Matte, Ph., H. Maluski, R. Caby, A. Nicolas, P. Kepezhinskas and S. Sobolev, Geodynamic model and ${ }^{39} \mathrm{Ar} /{ }^{40} \mathrm{Ar}$ dating for the generation and emplacement of the high pressure (HP) metamorphic rocks in SW Urals, C. R. Acad. Sci. Paris, 317, 1667-1674, 1993.

Mengel, K. and H. Kern, Evolution of the petrological and seismic Moho; implications for the continental crust-mantle boundary, Terra Nova, 4, 109-116, 1992.

Mercier, L., J.-M. Lardeaux and P. Davy, On the tectonic significance of retrograde P-T-t paths in eclogites of the French Massif Central, Tectonics, 10, 131-140, 1991.

Nelson, K. D., J. H. McBride, J. A. Arnow, D. M. Wille, L. D. Brown, J. E. Oliver and S. Kaufman, Results of recent COCORP profiling in the Southeastern United States, Geophys, J. Royal Astronom. Soc., 89, 141-146, 1987.

Perez Estaun, A., J. Alvarez Marron, D. Brown, V. N. Puchkov, Y. Gorozhanina and V. Baryshev, Along-strike structural variations in the foreland thrust and fold belt of the Southern Urals, Tectonophysics, 276, 1997

Pin, C. and D. Vielzeuf, Granulites and related rocks in Variscan median Europe; a dualistic interpretation, Tectonophysics, 93, 47-74, 1983
Piwowar, T. J., J. H. Knapp and G. Danukalova, Long wavelength Cenozoic flexural uplift across the Southern Urals and Central Eurasia, Geol. Soc. Am., Denver, Colorado, Abst., A172, 1996.

Platt, J. P. and P. C. England, Convective removal of lithosphere beneath mountain belts; thermal and mechanical consequences, Am. J. Sci. 294, 307-336, 1994.

Poli, S. and M. W. Schmidt, The high-pressure stability of hydrous phases in orogenic belts: an experimental approach on eclogite-forming processes, Tectonophysics, 273, 169-184, 1997.

Puchkov, V. N., Geodynamic control of regional metamorphism in the Urals, Geotectonics, 30, 97-113, 1996.

Rodgers, J., Fold-and-thrust belts in sedimentary rocks; Part 1, Typical examples, Am. J. Sci., 290, 321-359, 1990.

Sapin, M. and A. Hirn, Seismic structure and evidence for eclogitization during the Himalayan convergence, Tectonophysics, 273, 1-16, 1997.

Schreyer W, and B. Stöckhert, High-Pressure metamorphism in nature and experiment, Lithos, 41, 1997.

Sengör, A. M. C., B. A. Natal'in and B. S. Burtman, Evolution of the Altaid tectonic collage and Paleozoic crustal growth in Eurasia, Nature, 364, 299-307, 1993.

Seward, D., A. Perez-Estaun and V. Puchkov, Preliminary fission-track results from the southern Urals-Sterlitamak to Magnitogorsk, Tectonophysics, 276, 281-290, 1997.

Skripiy, A. A. and N. K. Yunusov, Tension and compression structures in the articulation zone of the Southern Urals and the East European Platform, Geotectonics, 23, 515-522, 1989.

Smith, A. G., Late Cenozoic uplift of stable continents in a reference frame fixed to South America, Nature, 296, $400-404,1982$.

Spakman, W. S. van der Lee and $\mathbf{R}$. van der Hilst, Travel-time tomography of the European-Mediterranean mantle down to $1400 \mathrm{~km}$, Phys. Earth Planet. Interiors, 79, 374, 1993.

Spear, F. S., Metamorphic phase equilibria and pressuretemperature-time paths, Monograph Series, 1, Mineral. Soc. Am., Washington, D.C., 799 pp., 1993.

Stadtlander, R., J. Mechie and A. Schulze, Deep structure of the Southern Ural mountains as derived from wide-angle seismic data, Geophys. J. Int., 137, 501-515, 1999.

Steer, D. N., J. H. Knapp, L. D. Brown, H. P. Echtler, D. Brown and R. Berzin, Deep structure of the continental lithosphere in an unextended orogen: An explosive-source seismic reflection profile in the Urals (Urals Seismic Experiment and Integrated Studies (URSEIS 1995)), Tectonics, 17, 143-157, 1998.

Thouvenot, F., S. N. Kashubin, G. Poupinet, V. V. Makovskiy, T. V. Kashubina, P. Matte and L. Jenatton, The root of the Urals; evidence from wide-angle reflection seismics, Tectonophysics, 250, 1-13, 1995.

Wernicke, B. P., R. W. Clayton, M. N. Ducea, C. H. Jones, S. K. Park, S. D. Ruppert, J. B. Saleeby, J. K. Snow, L. J. Squires, M. M. Fliedner, G. R. Jiracek, G. R. Keller, S. L. Klemperer, J. H. Luetgert, P. E. Malin, K. C. Miller, W. D. Mooney, H. W. Oliver and R. A. Phinney, Origin of 
high mountains in the continents; the southern Sierra Nevada, Science, 271, 190-193, 1996.

Zakharov, O. A. and V. N. Puchkov, On the tectonic nature of the Maksutovo complex of the Ural-Tau zone, $28 \mathrm{pp}$, report, Ufimian Sci. Cent., Russ. Acad. of Sci., Ufa, Russia, 1994 (in Russian).

Zonenshain, L. P., V. G. Korinevsky, V. G. Kazmin, D. M. Pechersky, V, V. Khain and V. V. Matveenkov, Plate tectonic model of the south Urals development, Tecionophysics, 109, 95-135, 1984.
Zonenshain, L. P., M. I. Kuzman and L. M. Natopov, Geology of the USSR: A plate-tectonic synthesis, Geodyn. Ser., 21, Amer. Geophys. Un., Washington, D.C., 25-54, 1990 .

Camelia C. Diaconescu and James H. Knapp, Department of Geological Sciences, University of South Carolina, Columbia, SC 29208 